\section{Japan ramps up patent effort to keep iPS lead}

As the battle to create therapeutic stem-cell lines intensifies, Japan is waking up to the fact that the United States could steal a march on it by being the first to commercialize induced pluripotent stem (iPS) cell technology.

Shinya Yamanaka and his colleagues at Kyoto University pioneered the creation of iPS cells, and the technology is seen as something of a national industry - albeit one in its extreme infancy. Like embryonic stem (ES) cells, human iPS cells have the potential to develop into any of the body's cell types, and are expected to have tremendous value in drug screening and for therapeutic purposes. They are easier to produce than ES cells and are not associated with the same controversial source - iPS cells can be derived from adult cells rather than embryonic cells.

On the same day in November 2007 that Yamanaka reported his human iPS cells ${ }^{1}$, James Thomson's team at the University of Wisconsin-Madison separately published similar results ${ }^{2}$. The details of any patents applied for by either party are not known - in Japan, as in Europe, a patent is awarded to the researchers who file first; in the United States, the patent goes to the group that can show it invented the technology first (see 'Broader coverage').

Kyoto University stalled over developing a taken a turn for the worse". corporate social responsibility." strategy to protect its patents because of a lack of legal expertise on involvement with industry. This has caused much anxiety in the Japanese media, with pundits fretting over what they see as imminent US ascendancy in the field. The Nikkei Keizai Shimbun newspaper, for example, notes that presentations on iPS cells by non-Japanese groups had arrived "one after the other" at last week's meeting of the International Society for Stem Cell Research in Philadelphia, adding that "Japan should be leading in iPS technology, but things have

This might be about to change, though, with the launch of 'iPS Academia Japan', a company set up to manage Kyoto University's iPS patents. The company, which is due to start up within a month, will be backed by around $¥ 1.2$ billion (US\$11 million) from a fund created jointly in May by Daiwa Securities Group, the Sumitomo Mitsui bank and NIF SMBC Ventures, a private Japanese equity company. A Daiwa Securities representative says that no return is expected, "at least not in the short term. It is a form of

A central purpose of iPS Academia Japan is "to prevent some group or company from monopolizing iPS technology", says Hiroshi Matsumoto, Kyoto University's executive

\section{Broader coverage}

The potential patentability of induced pluripotent stem (iPS) cells got a boost last December. The Wisconsin Alumni Research Foundation (WARF), which controls James Thomson's embryonic stem (ES) cell patents, had tried to extend the coverage of its patents to cover all pluripotent stem cells, including iPS cells. The ES-cell patents have been a thorn in and consumer activists, who feel they are unduly restrictive. Last year, the US patent office rejected the three patents in question. But in February and March of this year it reversed the the side of many researchers decision. The patents had been challenged because it was claimed the technology was the same as that used to derive mouse ES cells. But in the end the patent office recognized differences in the cells. For example, mouse cells express a surface protein, SSEA-1, not expressed in the human version.

The US patent office rejected WARF's claim that the human ES-cell patents cover all pluripotent stem-cell lines, because some pluripotent stem cells show variations (for example, some human germ cells do express SSEA-1). Such physical characteristics may be used to differentiate cell lines in the future, giving patent opportunities to those working on other routes to pluripotency.

"Shinya Yamanaka's iPS lines (and possibly Thomson's iPS lines, depending on who got there first) may fall outside the original WARF patents," says Christopher Thomas Scott of Stanford University's Program on Stem Cells in Society.

WARF is preparing to push the commercial potential of its own iPS patents, as it did with its ES-cell patents. "We are talking to business and industry to gain input for our plan, which we hope to complete this year," says Janet Kelly, WARF communications director.

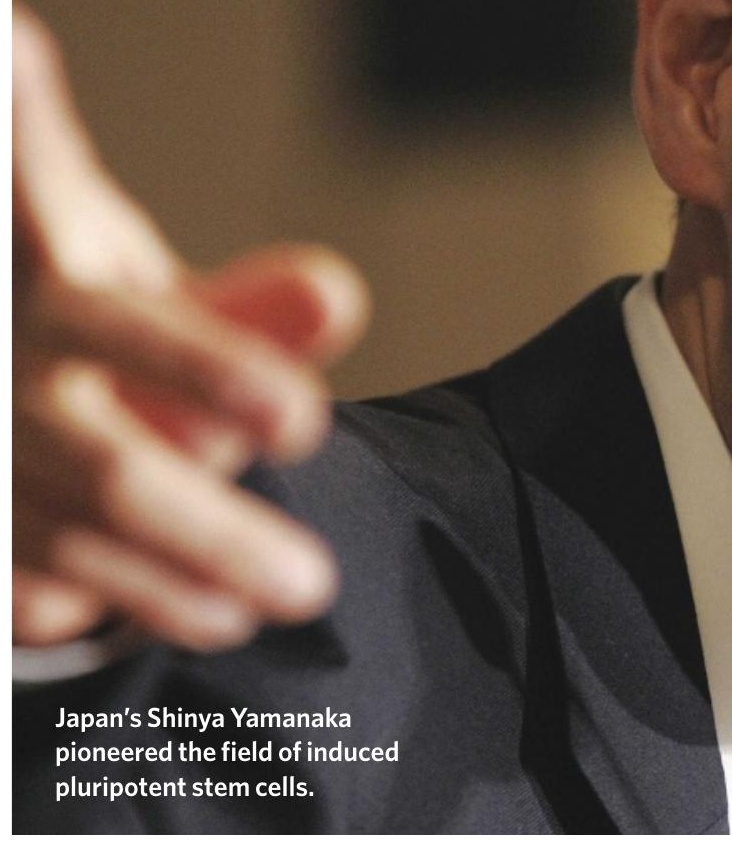

vice-president, who has been heading the dealings between the university and the investors.

It may already be too late. Kazuhiro Sakurada, who led the research arm of drug company Bayer Yakuhin in Kobe, is now chief scientific officer of iZumi Bio in San Francisco, California, a company set up to commercialize iPS cells. In April, reports claimed that Sakurada had created his own iPS cells in April 2007 while at Bayer Yakuhin, even though his results were not published until this January ${ }^{3}$. There are unconfirmed reports that Yamanaka did not create his first cells until July 2007, and it is not known who would hold the critical patent. Although Yamanaka has patents from his original iPS work in mice, it is not clear whether these patents will cover human iPS cells. Neither Sakurada nor Yamanaka would comment on the issue.

Little is known about iZumi Bio, and this exacerbates Japanese fears. The company is in "stealth mode", according to a spokesperson at Burson-Marsteller, the public-relations firm representing iZumi in Tokyo. It has a skeletal website (www.izumibio.com) that presents only its mission statement: to use "the power of induced pluripotent stem (iPS) cells to transform drug discovery and regenerative medicine". Yutaka Teranishi, who heads Kyoto University's intellectual-property office, says there is currently no formal relationship between the university and iZumi. But he adds: "We would be ready to license the technology to any partner ready to [develop iPS-cell technology for the benefit of patients]."

Thane Kreiner, chief executive of iZumi Bio, told Nature only that the company is funded 


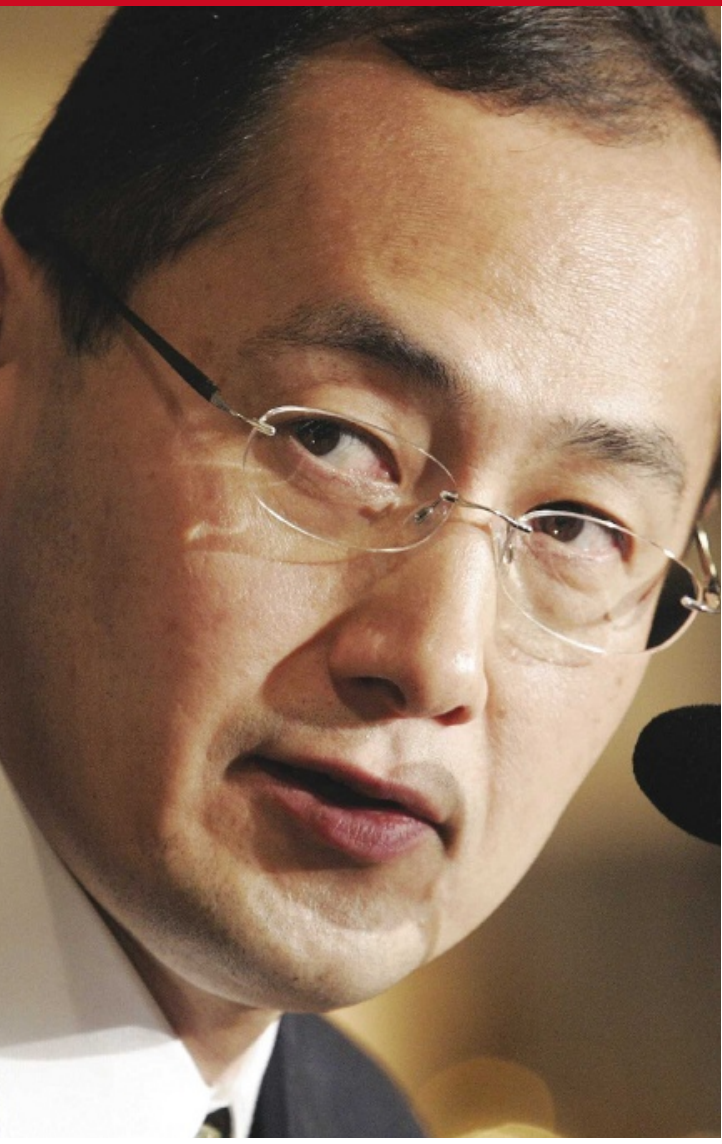

by Kleiner Perkins Caufield and Byers, the high-powered venture-capital company that helped create Genentech, and Highland Capital Partners. "iZumi is engaging in discussions with various potential partners," Kreiner says, and would not discuss the company's business model further. But on Monday, iZumi announced "a major research collaboration and licensing agreement to focus on applications for iPS cells" with Gladstone Institutes, based in San Francisco. Yamanaka has a joint position there.

Rumours abound in the normally conservative Japanese press. The magazine Nikkei Biotechnology \& Business reports that iZumi has been collecting "iPS cell patents from all over the world", and has already licensed ESand iPS-cell-related patents from Harvard University and the Massachusetts Institute of Technology (MIT) in Cambridge. Representatives of the intellectual-property office at MIT deny the report. Counterparts at Harvard say "we have no news to report" with regard to the patents. Kreiner says the patents in question have not even been issued. "It is clearly too early to discuss," he says.

"iZumi would like to work closely with Japan, and we celebrate Japan's scientific leadership," Kreiner told Nature. "Yamanaka and Sakurada as well as Thomson have made significant contributions," he says, acknowledging that it was Yamanaka's work on iPS cells in mice that was the starting point for the whole field. David Cyranoski

1. Takahashi, K. et al. Cell 131, 861-872 (2007)

2. Yu, J. et al. Science 318, 1917-1920 (2007)

3. Masaki, H. et al. Stem Cell Res. 1, 105-115 (2007)

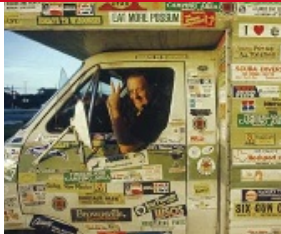

ALLTHE RAGE

Why bumper stickers are linked to aggressive driving. www.nature.com/news

\section{Institutes in pharma cash probe}

Until about three years ago, researchers at Duke University in Durham, North Carolina, declared their financial conflicts of interest by filling in a simple form. "It basically just asked: do you have a relationship with a company that might entail a conflict of interest?" says James Siedow, Duke's vice-provost for research.

The form has since been changed every year, becoming more complex with each new iteration. Now, Duke researchers are asked to estimate how much money they receive from industry sources. If that value is more than US $\$ 25,000$, they are required to delve into specifics. Although Siedow believes that most researchers filled in their forms accurately, he suspects that some were not forthcoming. “There were folks who didn't check that '\$25,000 or more' box, yet we're almost certain they should have," he says.

Pressure has been mounting on universities and hospitals to crack down on conflicts of interest. This month, Senator Charles Grassley (Republican, lowa) informed Congress that three high-profile psychiatrists at Harvard Medical School may have failed to disclose a total of about $\$ 4$ million of industry earnings over the course of seven years. Last August, Grassley disclosed that a researcher at the University of Cincinnati in Ohio had underreported industry earnings from a company that made a drug she had tested in clinical trials. And Grassley has informed the National Institutes of Health (NIH) that he is investigating other cases at more than 20 different institutions.

The NIH has made its stand on the issue clear: it is up to individual universities and hospitals to monitor their researchers, says deputy director of extramural research Norka Ruiz Bravo. The NIH may punish individual investigators by abridging or terminating their grants, but in cases where the misconduct seems to be systemic, sanctions could be levied against an entire institution.

But university administrators say they are unable to verify what their researchers disclose. "It's an honour system," says Robert Alpern, dean of the Yale School of Medicine. "We rely on the faculty to tell us the truth. And to be honest, up until a few months ago, I think we all thought they were telling us the truth."

Grassley has proposed legislation, called the Physician Payments Sunshine Act, that would require manufacturers of drugs and medical devices to disclose how much they pay doctors. The act would present institutions with a way to verify the sums their researchers have declared, and both the American Association of Medical Colleges and PhRMA, a lobbying group for the pharmaceutical industry, have praised the proposed act for increasing transparency. But the current draft of the legislation applies only to physicians and leaves out those researchers who do not practise medicine. Philip Pizzo, dean of Stanford Medical School, says he supports the act but acknowledges that it will come at a price. "This will not be an easy or inexpensive process," says Pizzo, who notes that schools may need to hire additional staff to process the new data.

Meanwhile, Siedow says that Duke administrators plan to interview researchers they suspect of not disclosing their earnings. Grassley's recent findings have bolstered Duke's efforts to improve its reporting system. "We can see the writing on the wall in Congress," says Siedow. "We don't want to find out from a pharmaceutical company that one of our researchers made half a million dollars that we didn't know about."

Heidi Ledford

See Editorial, page 957.

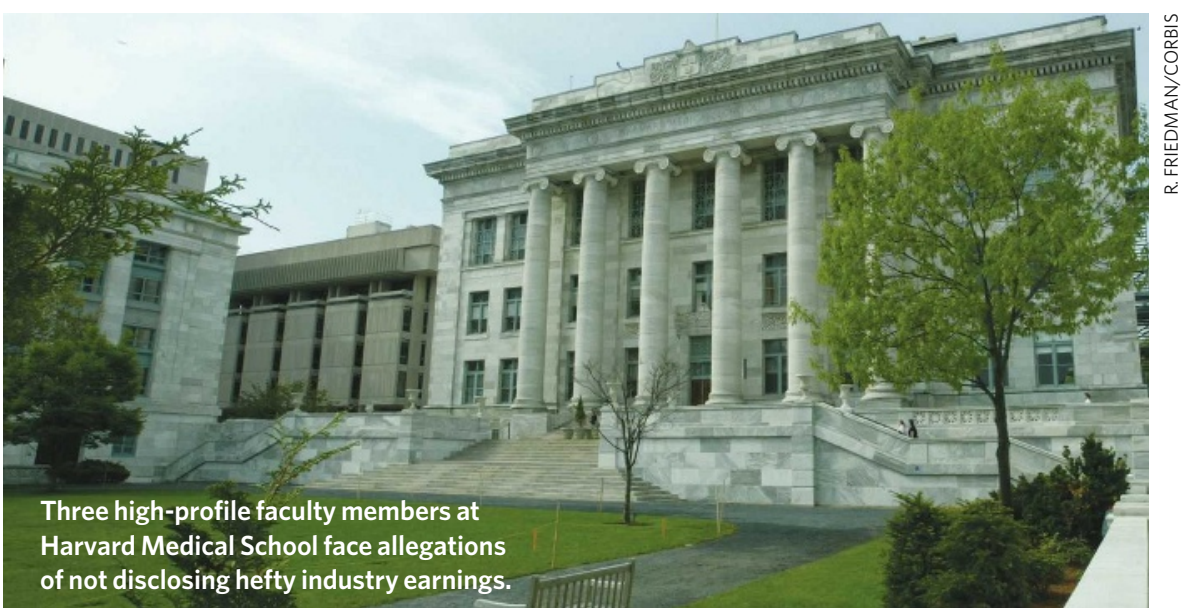

